\title{
Psychometric Evaluation Of Appetite Questionnaires In Elderly Polish Patients With Heart Failure
}

This article was published in the following Dove Press journal:

Patient Preference and Adherence

\author{
Marta Wleklik (iD) \\ Magdalena Lisiak (D) \\ Christina Andreae (iD) $2-4$ \\ Izabella Uchmanowicz (iD) \\ 'Department of Clinical Nursing, \\ Wrockaw Medical University, Wroclaw, \\ Poland; ${ }^{2}$ Division of Nursing Science, \\ Linköping University, Linköping, Sweden; \\ ${ }^{3}$ Centre for Clinical Research Sörmland, \\ Uppsala University, Uppsala, Sweden; \\ ${ }^{4}$ Department of Medicine, Region \\ Sörmland, Nyköping, Sweden
}

Purpose: Loss of appetite is caused by multifaceted disorders and affects an average of $40 \%$ of patients with heart failure (HF). The Council on Nutrition Appetite Questionnaire (CNAQ) and the Simplified Nutritional Appetite Questionnaire (SNAQ) are designed to assess appetite among older adults. We aimed to assess the psychometric properties of both CNAQ and SNAQ questionnaires in elderly Polish patients with HF.

Methods: The study sample involved 103 patients aged $\geq 65$ years with HF diagnosed according to the New York Heart Association (NYHA) functional classes II-IV. The study was conducted among hospitalized patients with HF. In the study, the Mini Nutritional Assessment (MNA) questionnaire was used to assess the validity of the questionnaire. The evaluation of the following psychometric values was taken into account: data quality and homogeneity, factor structure, construct validity and internal consistency.

Results: Parallel analysis confirmed the unidimensional structure of both CNAQ and SNAQ. The adjusted eigenvalues for CNAQ were 3.50 for the first factor and 0.62 for the second factor, and for SNAQ they were 2.2 and 0.31, respectively. For CNAQ, the desired CFA values were obtained after modification (RMSEA $<0.06$, CFI, TLI $>0.95$ ), for SNAQ without modification (RMSEA $<0.06, \mathrm{CFI}$, TLI $>0.95$ ). The correlation between CNAQ and SNAQ and MNA was strong ( $\mathrm{rs}=0.8$ and $\mathrm{rs}=0.81, \mathrm{p}<0.001$, respectively). The internal consistency of the CNAQ and SNAQ tools was 0.88 and 0.86 , respectively.

Conclusion: The CNAQ and SNAQ questionnaires have positive psychometric properties and can be used to evaluate appetite among elderly Polish patients with HF.

Keywords: appetite, elderly, heart failure, nutritional status

\section{Introduction}

According to epidemiological data, malnutrition in patients with heart failure (HF) affects approximately $69 \%$ of patients and is a negative prognostic factor, increasing the risk of hospitalization, rehospitalization and death. ${ }^{1,2}$ In addition, scientific studies have identified a relationship between malnutrition and prolonged hospitalization, increased treatment costs, postoperative complications, the risk of pressure ulcer development, complicated wound healing, increased risk of falls, pneumonia or renal failure. ${ }^{3,4}$ The European Society of Cardiology (ESC) guidelines for the treatment of acute and chronic HF contain information on the need to monitor and prevent malnutrition. ${ }^{5}$ However, there are no explicit recommendations that could be implemented in everyday clinical practice.

The concept of appetite refers to the desire to eat food to satisfy bodily needs, and the lack of appetite will be understood as aversion or a reduced desire to eat. ${ }^{6,7}$ The Council on Nutrition Appetite Questionnaire (CNAQ) and its shorter version,
Correspondence: Izabella Uchmanowicz Department of Clinical Nursing, Faculty of Health Sciences, Wrocław Medical University, Bartla 5, Wroclaw 5I-6I8, Poland

Tel +48 7I 7841824

Fax +48713419533

Email izabella.uchmanowicz@umed.wroc.pl 
the Simplified Nutritional Appetite Questionnaire (SNAQ), are measurement tools designed to assess appetite among older adults. CNAQ consists of 8 questions, while SNAQ's abbreviated version consists of only 4 questions. Wilson et al. ${ }^{8}$ describe the beneficial psychometric properties of both tools, which are simple to use, generic, and applicable to various clinical situations. By assessing appetite, these questionnaires identify an important factor that can result in malnutrition in elderly HF, namely the risk of involuntary weight loss. ${ }^{8}$ Studies confirm that loss of appetite is a predictor of weight loss. ${ }^{9}$ The reasons for loss of appetite in elderly HF may be multifaceted, and include hormonal changes, pharmacotherapy or psychosocial factors, and coexisting depression. ${ }^{3,10}$

It is assumed that loss of appetite is in the cause and effect of malnutrition. Research shows that loss of appetite is strongly associated with protein malnutrition and is its early indicator. However, protein-energy malnutrition is a multifactorial problem. Among the factors that are important for the development of protein-energy malnutrition, in addition to appetite, are hospitalizations, loneliness, trouble climbing stairs, depressive symptoms, female sex, multiple diseases, high drug consumption, and limitations in everyday activities due to health problems. Patients with heart failure may have several factors predisposing to the development of protein-energy malnutrition, including loss of appetite as its early determinant. ${ }^{11,12}$

The majority of patients with heart failure are elderly and their number is steadily increasing. ${ }^{13}$ Loss of appetite is widespread in elderly people, as well as in patients with diagnosed HF. Loss of appetite increases the nutritional risk of elderly HF patients. Elderly patients with HF are therefore a group that is particularly prone to adverse health effects due to the occurrence of appetite disorders. Identification of the problem in this group of patients creates an opportunity to undertake targeted interventions in this area. The assessment of appetite in elderly HF patients should become a preliminary and permanent link in the prevention of malnutrition. In Poland there is still a high rate of rehabilitation of HF patients, hence the screening assessment of loss of appetite on admission to hospital enables the tool to be used in as many patients as possible. ${ }^{14}$ Moreover, it enables monitoring of appetite during hospitalization and identification of patients who require in-depth nutritional evaluation and support. The tools taken into account in this study may become useful in this regard, so the aim of this study is to assess the psychometric properties of the CNAQ and SNAQ in a group of elderly Polish patients with HF. According to our knowledge, there are no studies concerning appetite disorders in the population of Polish patients with HF.

\section{Methods \\ Type Of Study}

Validation study.

\section{Sample And Procedure}

Data for the analysis was collected from patients diagnosed with HF, according to the New York Heart Association (NYHA) functional classes II-IV. The study group consisted of 115 patients, 12 of whom either withdrew from the study or did not answer the questionnaires in full $(10.43 \%)$. The data was collected by the nurse responsible for the study among patients hospitalized in the Department of Internal Medicine in Wroclaw, Poland. The study was carried out when the patient was admitted to the hospital in order to eliminate the possible impact of in-hospital factors on loss of appetite.

The inclusion criteria for patients in the study were: age $\geq 65$ years, HF confirmed in their medical documentation and echocardiography, no requirement for intensive cardiac care, no dementia or coexisting cancer, and written informed consent for participation in the study. Only those questionnaires that did not lack any of the possible answers were included in the study.

\section{Ethical Considerations}

Before the study, all patients signed written informed consent forms and were made aware of all their rights, including the right to withdraw from the study at any stage. The study was carried out in accordance with the tenets of the Declaration of Helsinki and the guidelines of Good Clinical Practice. ${ }^{15}$ The study protocol was approved by the independent Bioethics Committee of the Wroclaw Medical University, Poland (approval no. KB283/2017).

\section{Measurement Tools}

The sociodemographic and clinical data used in this study were collected from each patient by analyzing their medical records (NYHA class, left ventricular ejection fraction - LVEF, body mass index - BMI, medications used) and interviewing them (sex, age, marital status, type of education). In addition, 3 standardized measurement tools were used. 


\section{Council On Nutrition Appetite Questionnaire (CNAQ)}

The first of these was the original version of the CNAQ, designed by Wilson et al. ${ }^{8}$ to assess appetite. This questionnaire investigates self-esteem in relation to various subjects, and the questions with their topics can be described as follows: 1) appetite, 2) satiety, 3) hunger, 4-5) taste, 6) the number of meals consumed during the day, 7) nausea, and 8) mood. The score is calculated by adding up the points (values) that are assigned to the individual answers. The maximum number of points possible for a patient to obtain is 40 , while the minimum is 8 . The lower the score, the worse the patient's appetite. A cut-off score of $\leq 28$ points indicates poor appetite and classifies the patient as being at risk of significant weight loss within 6 months. $^{8}$ The particular CNAQ used was translated into Polish by 2 independent translators. Subsequently, the translated version was evaluated by a team of researchers consisting of 3 nurses, 1 doctor, and 1 psychologist. After verifying the content and correctness of the questionnaire, it was subjected to a retranslation process. After obtaining the final version, the CNAQ was subjected to a psychometric assessment in the present study. The translation process was carried out in accordance with the World Health Organization (WHO) recommendations. The original and Polish version of the CNAQ is shown in Table 1 .

\section{Simplified Nutritional Appetite Questionnaire (SNAQ)}

The second measurement tool was the SNAQ, a shorter version of the CNAQ that consists only of the CNAQ's first, second, fourth, and sixth questions. Scoring ranges from 4 to 20 points. A cut-off score $\leq 14$ points indicates poor appetite with the risk of significant weight loss within 6 months.

Table I Original And Polish Version Of The CNAQ And The SNAQ

\begin{tabular}{|c|c|c|}
\hline Item & $\begin{array}{l}\text { Original English Version } \\
\text { Council On Nutrition Appetite Questionnaire [8] }\end{array}$ & $\begin{array}{l}\text { Translated Polish Version } \\
\text { Kwestionariusz Apetytu Rady ds. Żywienia }\end{array}$ \\
\hline$A^{* *}$ & $\begin{array}{l}\text { My appetite is: I) Very poor; 2) Poor; 3) Average; 4) Good; 5) Very } \\
\text { good. }\end{array}$ & $\begin{array}{l}\text { Poziom mojego apetytu określił(a)bym jako: I) Bardzo słaby; 2) } \\
\text { Słaby; 3) Przeciętny; 4) Dobry; 5) Bardzo dobry. }\end{array}$ \\
\hline $\mathrm{B}^{* *}$ & $\begin{array}{l}\text { When I eat: I) I feel full after eating only a few mouthfuls; 2) I feel } \\
\text { full after eating about a third of a meal; 3) I feel full after eating } \\
\text { over half a meal; 4) I feel full after eating most of a meal; 5) I hardly } \\
\text { ever feel full. }\end{array}$ & $\begin{array}{l}\text { Kiedy jem, czuje się najedzony/a: I) Już po kilku łyżkach/kęsach; 2) } \\
\text { Po zjedzeniu ok. Jednej trzeciej posiłku; 3) Po zjedzeniu ponad } \\
\text { połowy posiłku; 4) Po zjedzeniu większej części posiłku; 5) Prawie } \\
\text { nigdy. }\end{array}$ \\
\hline C & $\begin{array}{l}\text { I feel hungry I) Rarely; 2) Occasionally 3) Some of the time; 4) } \\
\text { Most of the time; 5) All of the time. }\end{array}$ & $\begin{array}{l}\text { Odczuwam głód: 1) Nigdy; 2) Rzadko; 3) Czasami; 4) Przez } \\
\text { większość czasu; 5) Cały czas; }\end{array}$ \\
\hline $\mathrm{D}^{* *}$ & $\begin{array}{l}\text { Food tastes: I) Very bad; 2) Bad; 3) Average; 4) Good; 5) Very } \\
\text { good. }\end{array}$ & $\begin{array}{l}\text { Jedzenie smakuje: I) Bardzo źle; 2) Źle; 3) Przeciętnie; 4) Dobrze; } \\
\text { 5) Bardzo dobrze. }\end{array}$ \\
\hline$E$ & $\begin{array}{l}\text { Compared to when I was younger, food tastes: I) Much worse; 2) } \\
\text { Worse; 3) Just as good; 4) Better; 5) Much better. }\end{array}$ & $\begin{array}{l}\text { W porównaniu z okresem, gdy miałem/am } 50 \text { lat, jedzenie } \\
\text { smakuje: I) Dużo gorzej; 2) Gorzej; 3) Tak samo; 4) Lepiej; 5) } \\
\text { Dużo lepiej; }\end{array}$ \\
\hline$F^{* *}$ & $\begin{array}{l}\text { Normally I eat: I) Less than one meal a day; 2) One meal a day; } 3 \text { ) } \\
\text { Two meals a day; 4) Three meals a day; 5) More than three meals a } \\
\text { day. }\end{array}$ & $\begin{array}{l}\text { Zazwyczaj zjadam: I) Mniej niż jeden stały posiłek dzienne; 2) } \\
\text { Jeden posiłek dziennie; 3) Dwa posiłki dziennie; 4) Trzy posiłki } \\
\text { dziennie; 5) Więcej niż trzy posiłki dziennie (włączając przekąski); }\end{array}$ \\
\hline G & $\begin{array}{l}\text { I feel sick or nauseated when I eat: I) Most times; 2) Often; 3) } \\
\text { Sometimes; 4) Rarely; 5) Never. }\end{array}$ & $\begin{array}{l}\text { Kiedy jem jest mi niedobrze lub odczuwam mdłości: I) Prawie } \\
\text { zawsze; 2) Często; 3) Czasami; 4) Rzadko; 5) Nigdy; }\end{array}$ \\
\hline $\mathrm{H}$ & $\begin{array}{l}\text { Most of the tome my mood is: I) Very sad; 2) Sad; 3) Neither sad } \\
\text { nor happy; 4) Happy; 5) Very happy. }\end{array}$ & $\begin{array}{l}\text { Mój nastrój określił(a)bym zazwyczaj jako: I) Bardzo zły; 2) Zły; 3) } \\
\text { Ani dobry, ani zły; 4) Dobry; 5) Bardzo dobry; }\end{array}$ \\
\hline Scoring & $\begin{array}{l}\text { *The results are calculated by adding the numbers assigned to the } \\
\text { patient's response. A total of less than } 28 \text { should be a cause a } \\
\text { concern. }\end{array}$ & $\begin{array}{l}\text { *Wynik obliczamy poprzez zsumowanie cyfr powiązanych z } \\
\text { odpowiedziami pacjenta. Wynik niższy niż } 28 \text { stanowi powód do } \\
\text { niepokoju. }\end{array}$ \\
\hline
\end{tabular}

Notes: *Answers scored based on the following numerical scale: $a=1 ; b=2 ; c=3 ; d=4 ; e=5$. **Questions of the SNAQ.

Abbreviations: CNAQ, The Council on Nutrition Appetite Questionnaire; SNAQ, The Simplified Nutritional Appetite Questionnaire. 


\section{Mini Nutritional Assessment (MNA)}

The last measurement tool was the full version of the MNA questionnaire which is used to identify malnutrition or nutritional risk, and is particularly recommended for use in the elderly. ${ }^{16}$ MNA consists of 2 parts. The first part is a screening test, where obtaining 12-14 points indicates the correct nutritional status, obtaining $8-11$ points indicates the risk of malnutrition, and obtaining $\leq 7$ points indicates malnutrition. The initial version of MNA contains questions about eating restrictions, weight loss in the last three months, mobility, and neuropsychological disorders, BMI). The second part of the questionnaire asks for a patient's subjective assessment. This part of the questionnaire concerns the place of residence, medicines taken, the occurrence of skin lesions, the number of meals consumed, foods specifying the intake of protein, consuming fruits and vegetables, the amount of fluids taken, diet and selfesteem. In addition, mid-arm circumference in $\mathrm{cm}$ (MAC) and calf circumference in $\mathrm{cm}(\mathrm{CC})$ is determined. The total MNA score consists of the screening scoring and subjective patient evaluation. Normal nutritional status is indicated by scores $\geq 24$ points, $17-23.5$ points are at risk of malnutrition and scores below 17 points are at risk of malnutrition. ${ }^{16}$ In these analyses, the MNA questionnaire was used to assess the validity of the CNAQ and SNAQ. The MNA questionnaire contains questions related to loss of appetite, hence strong correlations between the tools used were predicted.

\section{Statistical Analysis}

In the data analysis, descriptive statistics were used to evaluate the associations between individual item scores and the overall score. In order to evaluate the relationship between the scores obtained in each question and the total score, item-total correlations were applied based on multicore correlations, where the acceptable rho was $>0.3 .^{17}$

Measurement structure is an important element in determining the validity of a structure, and factor analysis was used to assess the measurement structures of the CNAQ and SNAQ. First, a parallel analysis based on a polychoric correlation matrix (i.e., the correlation coefficients of ordinal data), was performed to determine the number of factors. Then, Confirmatory Factor Analysis (CFA) was performed to assess the fit of the measurement models. Individual questions (items) were treated as ordinal indicator variables, so the parameters were evaluated using a significant estimator of weighted averages and variances.
After indicating theoretically possible modifications, the parameters were reevaluated for a better model fit. The reevaluated fit of the model indicated a negligible $\chi^{2}$ test that could be significant for larger samples. Because the use of comparative matching indices are usually recommended to avoid type II errors when assessing the adequacy of a model, the following criteria were used to determine an acceptable model fit: the Root Mean Square Error of Approximation (RMSEA) $\leq 0.06$, the Comparative Fit Index (CFI) $\geq 0.95$, the Tucker-Lewis Ratio (TLR) $\geq 0.95$, and the Standardized Root Mean Square Residual $($ SRMR) $<0.08$. For further analysis of validity, the relationship between appetite and malnutrition was assessed by means of rho Spearman's (rs) coefficient. Strong correlations ( $r s>0.6$ ) were expected because the evaluated the CNAQ and SNAQ and the MNA questionnaire measure quite similar constructs. ${ }^{18,19}$

Using NYHA classifications, the validity of a known group was assessed by using the Mann-Whitney $U$-test to compare the CNAQ and SNAQ scores of those patients in functional class II with those patients in functional classes III-IV. Because the severity of HF symptoms may be associated with worsened appetite, it was assumed that patients in functional classes III-IV would produce poorer CNAQ and SNAQ results than those patients in functional class II.

The reliability of the internal consistency of the tools was assessed using the ordinal version of the alpha coefficient with a value $\geq 0.7$ indicating adequate reliability. ${ }^{18,19}$ The statistical analysis was carried out using the $\mathrm{R}$ software application, version 3.5.0 (R Core Team, 2017). ${ }^{20}$

\section{Results}

\section{Demographic And Clinical Characteristics}

Of the 103 patients who participated in the study, the following statistics were observed: $52.43 \%$ were men, $52 \%$ were $65-76$ years old and $48 \%$ were $\geq 77$ years old. Most lived alone (62\%). Using NYHA classifications, $32 \%$ were in functional class II, $45 \%$ were in functional class III, and $23 \%$ were in functional class IV. $37 \%$ lowered, $42 \%$ indirect and $21 \%$ preserved LVEF was reported. In $33 \%$ of patients, the BMI index was reduced, in $49 \%$ it was normal and in $18 \%$ the rate was high. For the BMI index, the cut-off point indicating the underweight was considered $<23 \mathrm{~kg} / \mathrm{m} 2$. The cut-off point was adopted in reference to the meta-analysis of Winter et al., ${ }^{21}$ where in 
person's $\geq 65$ years of age was correlated with an increase in mortality. In the multiple choice question about pharmacotherapy, it was reported that $79 \%$ were taking $\beta$-blockers, 78\% diuretics, 73\% angiotensin-converting enzyme (ACE) inhibitors or angiotensin II receptor blockers (ARB), and 13\% digoxin. Sociodemographic and clinical variables are included in Table 2 .

\section{Data Quality And Item Homogeneity}

There were no missing answers in any of the items. All of the answers from the questionnaires were used, except for

Table 2 Sociodemographic And Clinical Characteristics Of The Study Participants $(n=103)$

\begin{tabular}{|c|c|c|c|}
\hline \multicolumn{2}{|l|}{ Parameter } & \multirow{3}{*}{$\begin{array}{l}\mathbf{n} \\
54 \\
49\end{array}$} & \multirow{3}{*}{$\begin{array}{l}\% \\
52 \\
48\end{array}$} \\
\hline Sex & Women & & \\
\hline & Men & & \\
\hline \multirow[t]{5}{*}{ Age } & $65-70$ years & 36 & 35 \\
\hline & $7 \mathrm{I}-76$ years & 18 & 17 \\
\hline & $77-82$ years & 17 & 17 \\
\hline & $83-88$ years & 21 & 20 \\
\hline & $>88$ years & 11 & II \\
\hline \multirow[t]{2}{*}{ Marital status } & Single & 64 & 62 \\
\hline & In relationship & 39 & 38 \\
\hline \multirow[t]{4}{*}{ Education } & None or primary & 9 & 9 \\
\hline & Vocational & 33 & 32 \\
\hline & Secondary & 35 & 34 \\
\hline & Higher & 26 & 25 \\
\hline \multirow[t]{3}{*}{ NYHA class } & II & 33 & 32 \\
\hline & III & 46 & 45 \\
\hline & IV & 24 & 23 \\
\hline \multirow[t]{3}{*}{ LVEF (\%) } & $<40$ & 38 & 37 \\
\hline & $40-49$ & 43 & 42 \\
\hline & $\geq 50$ & 22 & 21 \\
\hline \multirow[t]{3}{*}{ BMI $\left(\mathrm{kg} / \mathrm{m}^{2}\right)$} & $<22.9$ & 34 & 33 \\
\hline & $23-30.9$ & 50 & 49 \\
\hline & $>31$ & 19 & 18 \\
\hline \multirow[t]{4}{*}{ Medications* } & Diuretics & 81 & 79 \\
\hline & ACE inhibitors/ARB & 75 & 73 \\
\hline & $\beta$ - adrenolytics & 82 & 80 \\
\hline & Digoxin & 13 & 13 \\
\hline \multirow[t]{3}{*}{ MNA } & Malnourished & 52 & 50 \\
\hline & At risk of malnutrition & 45 & 44 \\
\hline & Normal nutritional status & 6 & 6 \\
\hline
\end{tabular}

Note: *Percentage does not add up to $100 \%$ because it was a multiple-choice question. Abbreviations: NYHA, New York Heart Association; LVEF, left ventricular ejection fraction; BMI, body mass index; ACE, angiotensin-converting enzyme; ARB, angiotensin II receptor blockers. the first answer in question 6 and the last answer in question 3 (zero in Table 3). The total score of the CNAQ did not show asymmetry. The skewness coefficient was 0.06 . The Shapiro-Wilk test showed no deviations from normality $(\mathrm{W}=0.982, \mathrm{p}=0.19)$. The total score of SNAQ had a skewness coefficient of 0.26 , which indicates a slight positive asymmetry. The Shapiro-Wilk test confirmed deviations from normality $(\mathrm{W}=0.972, \mathrm{p}=0.03)$. Homogeneity regarding item-total correlation for the CNAQ and SNAQ ranged between $0.47-0.84$ for CNAQ and $0.78-0.88$ for SNAQ (Table 3). The correlations between items and the combined results of the CNAQ and SNAQ were statistically significant, with $\mathrm{p}<0.001$.

\section{Factor Structure}

Parallel analysis confirmed the unidimensional structure of both the CNAQ and SNAQ, thus confirming the absence of the need to divide the measurement tools into subscales. The adjusted eigenvalues for the CNAQ were 3.50 for the first factor and 0.62 for the second factor, and for SNAQ were 2.2 and 0.31 , respectively.

CFA did not confirm a one-way CNAQ structure (RMSEA $>0.06$, CFI and TLI $<0.95$, in model I in Table 2). Thus, 2 modifications were indicated by modification indices: (1) correlations between item pairs 4 and 5, 2 and 4, 2 and 5, 2 and 3, and 5 and 6 were introduced into the model, and (2) desired parameter values were obtained (RMSEA $<0.06$, CFI and TLI $>0.95$, in model II in Table 4). This confirmed a one-factor structure with the proviso that the answers to the written questions were strongly correlated to each other. Many individual items ranged from 0.38 to 0.96 (Table 4) and were statistically significant. For SNAQ, in turn, the desired parameter values (RMSEA $<0.06$, CFI and TLI $>0.95$ ) were obtained without any modification. Many individual items ranged from 0.55 to 1.04 (Table 5) and were statistically significant.

\section{Construct Validity}

A further analysis of construct validity showed a strong correlation between the CNAQ and MNA (rs =0.8) and between the SNAQ and MNA (rs = 0.81), and both the CNAQ and SNAQ were statistically significant ( $p<0.001)$. The construct validity of the CNAQ scale was also confirmed by analysis of known-group validity using the NYHA classification. Patients in individual functional classes differed significantly in the CNAQ $(\mathrm{p}=0.008)$ and SNAQ ( $\mathrm{p}=$ 0.024). Patients in functional class II had CNAQ scores 
Table 3 Score Distribution And Homogeneity For CNAQ And SNAQ

\begin{tabular}{|l|l|l|l|l|l|l|l|}
\hline \multirow{2}{*}{ Item } & \multicolumn{2}{l}{ Score Distribution (\%) } & \multicolumn{2}{l|}{ Item-Total Correlation* } \\
\cline { 2 - 8 } & I & II & III & IV & V & CNAQ & SNAQ \\
\hline I. & 18.4 & 29.1 & 34 & 10.7 & 7.8 & 0.83 & 0.88 \\
2. & 9.7 & 33 & 32 & 22.3 & 2.9 & 0.79 & 0.85 \\
3. & 11.7 & 40.8 & 40.8 & 6.8 & 0 & 0.65 & - \\
4. & 12.6 & 30.1 & 42.7 & 10.7 & 3.9 & 0.84 & 0.80 \\
5. & 29.1 & 27.2 & 39.8 & 1.9 & 1.9 & 0.69 & - \\
6. & 0 & 8.7 & 47.6 & 33 & 10.7 & 0.71 & 0.78 \\
7. & 11.7 & 35 & 26.2 & 15.5 & 11.7 & 0.83 & - \\
8. & 2.9 & 16.5 & 39.8 & 37.9 & 2.9 & 0.47 & - \\
\hline
\end{tabular}

Notes: *Recommended level of rho was $>0.3$. I. My appetite is ... 2. When I eat ... 3. I feel hungry ... 4. Food tastes ... 5. Compared to when I was younger, food tastes ... 6. Normally, I eat ... 7. I feel sick or nauseated when I eat ... 8. Most of the time my mood is ...

Abbreviations: CNAQ, The Council on Nutrition Appetite Questionnaire; SNAQ, The Simplified Nutritional Appetite Questionnaire.

Table 4 Goodness-Of-Fit Indices For (CNAQ) And (SNAQ) $(n=103)$

\begin{tabular}{|c|c|c|c|c|c|c|c|c|c|}
\hline \multirow[t]{2}{*}{ Model } & \multicolumn{3}{|c|}{$\chi^{2}$ Goodness Of Fit } & \multicolumn{3}{|l|}{ RMSEA } & \multirow[t]{2}{*}{ CFI } & \multirow[t]{2}{*}{ TLI } & \multirow[t]{2}{*}{ SRMR } \\
\hline & $\chi^{2}$ & df & P Value & RMSEA & $90 \% \mathrm{Cl}$ & P Value & & & \\
\hline CNAQ - I & 65.04 & 20 & 0.00 & 0.15 & $0.11-0.19$ & 0.00 & 0.89 & 0.85 & 0.06 \\
\hline CNAQ - II & 18.06 & 14 & 0.20 & 0.05 & $0.00-0.12$ & 0.43 & 0.99 & 0.98 & 0.04 \\
\hline SNAQ & 1.93 & 2 & 0.38 & 0.00 & $0.00-0.19$ & 0.47 & I & I & 0.02 \\
\hline
\end{tabular}

Abbreviations: CNAQ, The Council on Nutrition Appetite Questionnaire; SNAQ, The Simplified Nutritional Appetite Questionnaire; RMSEA, Root Mean Square Error of Approximation; $\chi^{2}$, Chi-squared; df, degrees of freedom; Cl, confidence interval; CFI, Comparative Fit Index; TLI, Tucker-Lewis Index; SRMR, Standardized Root Mean Square Residual.

Table 5 Factor Loadings And Residual Variances For The Confirmatory Factor Analysis Models Of The CNAQ And SNAQ $(n=103)$

\begin{tabular}{|l|l|l|l|}
\hline Item & CNAQ - Model I & CNAQ - Model II & SNAQ \\
\hline I. & $0.96(0.36)$ & $0.96(0.37)$ & I.04 (0.22) \\
2. & $0.74(0.45)$ & $0.81(0.37)$ & $0.74(0.45)$ \\
3. & $0.45(0.4 I)$ & $0.43(0.43)$ & - \\
4. & $0.81(0.27)$ & $0.79(0.3 I)$ & $0.73(0.4)$ \\
5. & $0.59(0.55)$ & $0.62(0.52)$ & - \\
6. & $0.55(0.34)$ & $0.55(0.33)$ & $0.55(0.33)$ \\
7. & $0.96(0.48)$ & $0.93(0.53)$ & - \\
8. & $0.36(0.6)$ & $0.38(0.58)$ & - \\
\hline
\end{tabular}

Notes: I. My appetite is ... 2. When I eat ... 3. I feel hungry ... 4. Food tastes ... 5. Compared to when I was younger, food tastes ... 6. Normally, I eat ... 7. I feel sick or nauseated when I eat ... 8. Most of the time my mood is ...

Abbreviations: CNAQ, The Council on Nutrition Appetite Questionnaire; SNAQ, The Simplified Nutritional Appetite Questionnaire.

significantly higher than patients in functional class IV (the median difference is 5 points). Patients in functional class III were "suspended" between these 2 groups, and they did not significantly differ from either of them. However, patients in functional classes II and III had SNAQ scores significantly higher than patients in functional class IV (the median difference was 3.5 and 2.5 points, respectively).

\section{Internal Consistency}

Ordinal the Cronbach's alpha coefficient supported internal consistency reliability for both the CNAQ (0.88) and SNAQ (0.86).

\section{Discussion}

This paper attempts to adapt 2 questionnaires, the CNAQ and SNAQ, to Polish conditions in a population of HF patients. A psychometric analysis was performed by evaluating the construct validity, known-group validity, and internal consistency of the measurement tools. The original version of the questionnaires, originating in the United States, was published by Wilson et al., ${ }^{8}$ and was associated with the assessment of appetite in the elderly. In the present study, one of the inclusion criteria was the elderly age of HF patients. Studies show that the number of older adults with HF will increase significantly in the coming decades. It is expected that the largest, threefold increase, representing medical, social, and economic challenges, is to occur in the group of patients aged 70 and over. ${ }^{22}$

Publication on this subject is available in the literature of Andreae et al. ${ }^{23}$ who, analogically to this present study, assess the psychometric properties of the CNAQ and 
SNAQ in a group of Swedish patients with HF (Median age 72). Our own study confirms the one-way structure of the and SNAQ, which means that there is no need to divide the measurement tools into subscales. For comparison, the above-mentioned Swedish study ${ }^{23}$ also confirmed the one-factor structure of the tools, whereby the corrected properties obtained were slightly lower than in our analysis. The confirmed univariate structure of the questionnaire in both the Polish and Swedish study means that the tools should not be divided into subscales. However, it should be emphasized that the questions in the questionnaire ask about similar issues, as evidenced by the strong interrelationships between responses. Positive, statistically significant correlations have shown that a decrease in appetite is associated with the risk of HF-related malnutrition. In the construct validity assessment of the Swedish study, a tool evaluating depressive symptoms was used, and significant negative correlations were obtained. In the study, the occurrence of depressive symptoms negatively affected appetite, as measured by the CNAQ and SNAQ. ${ }^{23}$

In a study by Yaxley et al., ${ }^{24}$ which concerned the identification of malnutrition in a group of elderly patients undergoing outpatient rehabilitation, the MNA questionnaire was used in addition to the CNAQ and SNAQ, as in our own study. In the case of that analysis, the desired levels of accuracy and reliability were not obtained. Both in our own study and in the Swedish study, ${ }^{18}$ lower appetite ratios in patients in NYHA functional class IV have been demonstrated that in patients in functional class II. In the internal consistency assessment of our study, desirable Cronbach's alpha coefficients for the SNAQ and CNAQ were obtained, amounting to 0.88 and 0.86 , respectively. According to the literature data, the optimal Cronbach's alpha values are $\geq 0.90$. Values of $0.80-0.89$ are considered good, $0.70-0.79$ are acceptable, $0.60-0.69$ are doubtful, $0.50-0.59$ are weak, and $<0.5$ are unacceptable. ${ }^{25}$ In the Swedish study, ${ }^{23}$ as in our own study, positive indicators supporting the internal coherence of the evaluated measurement tools were obtained. ${ }^{23}$ Decreased appetite is an important symptom of deteriorating health in $\mathrm{HF} ;{ }^{6}$ hence, it is important to implement tools in everyday clinical practice that quickly and easily identify this symptom. As hospitalization may increase the nutritional risk in patients with heart failure, it would be most accurate to identify loss of appetite as an early indicator of malnutrition on admission and to monitor this indicator during hospitalization. Currently, the conditions of hospitalization provide the greatest opportunity to identify loss of appetite in a group of patients with heart failure. After the introduction of comprehensive care for a patient with heart failure in Poland, the identification of loss of appetite will also be possible in other places such as primary healthcare, which will have the task of coordinating the care of patients with NS. ${ }^{26}$ Although the SNAQ is a shorter and easier-to-use version of the questionnaire, we recommend using the full version (CNAQ), due to the greater reliability of the tool, which is also confirmed by the study by Anreae et al. ${ }^{23}$

There are a few potential limitations that should be discussed. First of all, the CNAQ and SNAQ, according to the authors of the original versions, predict the risk of weight loss. The present study did not include alterations in body weight or other important predictors, such as mortality, morbidity or hospitalization rates, among HF patients. In addition, appetite changes were not evaluated over a long period of time. The duration of HF and pharmacotherapy, both of which may also significantly affect the assessment of appetite in HF, were not included. Taking these factors into account could show whether loss of appetite varies according to the time of disease, whether taking certain medications co-exists with loss of appetite and, most importantly, whether loss of appetite changes during hospitalization of patients with HF. It would also be very important to determine what weight loss, expressed in kilograms, correlates with loss of appetite in HF. However, identifying the very problem of loss of appetite in all patients with HF admitted to hospital, taking the above factors into account was less important for the analysis. Taking into consideration the above limitations of the study will be useful in further studies related to the problem of loss of appetite in HF.

\section{Conclusion}

The CNAQ and SNAQ are both valid and reliable instruments that can be used to assess appetite in Polish patients with HF. The lower level of appetite associated with poorer nutrition status indicates that the instrument could be used in determining patients at risk of developing malnutrition. However, longitudinal studies are needed in order to evaluate the predictive value of the CNAQ and SNAQ to predict weight loss in Polish patients with HF. The CNAQ and SNAQ have positive psychometric properties and can be used to assess the appetite of Polish patients with HF. These questionnaires are short and easy to use, and this study indicates that their implementation in everyday clinical practice should be encouraged. 


\section{Abbreviations}

ACE, angiotensin-converting enzyme; ARB, angiotensin II receptor blockers; BMI, body mass index; CFA, Confirmatory Factor Analysis; CFI, Comparative Fit Index; CNAQ, Council on Nutrition Appetite Questionnaire; ESC, European Society of Cardiology; HF, heart failure; LVEF, left ventricular ejection fraction; MNA, Mini Nutritional Assessment; NYHA, New York Heart Association; RMSEA, Root Mean Square Error of Approximation; rs, rho Spearman's coefficient; SNAQ, Simplified Nutritional Appetite Questionnaire; SRMR, Standardized Root Mean Square Residual; TLR, Tucker-Lewis Ratio; WHO, World Health Organization.

\section{Acknowledgments}

We want to thank all participants for their contribution to this research. Copyright permission was not required to reproduce the CNAQ and SNAQ in Table 1.

\section{Disclosure}

The authors report no conflicts of interest in this work.

\section{References}

1. Narumi T, Arimoto T, Funayama A, et al. Prognostic importance of objective nutritional indexes in patients with chronic heart failure. $J$ Cardiol. 2013;62(5):307-313. doi:10.1016/j.jjcc.2013.05.007

2. Gámez-López AL, Bonilla-Palomas JL, Anguita-Sánchez M, et al. Rationale and design of PICNIC study: nutritional intervention program in hospitalized patients with heart failure who are malnourished. Rev Esp Cardiol. 2014;67(04):277-282. doi:10.1016/j.rec.2013.07.013

3. Wleklik M, Uchmanowicz I, Jankowska-Polańska B, Andreae C, Regulska-Ilow B. The role of nutritional status in elderly patients with heart failure. $J$ Nutr Health Aging. 2018;22(5):581-588. doi:10.1007/s12603-017-0985-1

4. Ruiz AJ, Buitrago G, Rodríguez N, et al. Clinical and economic outcomes associated with malnutrition in hospitalized patients. Clin Nutr Edinb Scotl. 2019;38(3):1310-1316. doi:10.1016/j.clnu.2018. 05.016

5. Ponikowski P, Voors AA, Anker SD, et al. 2016 ESC guidelines for the diagnosis and treatment of acute and chronic heart failurethe task force for the diagnosis and treatment of acute and chronic heart failure of the European Society of Cardiology (ESC) developed with the special contribution of the Heart Failure Association (HFA) of the ESC. Eur Heart J. 2016;37(27):2129-2200. doi:10.1093/eurheartj/ehw128

6. Andreae C, Strömberg A, Årestedt K. Prevalence and associated factors for decreased appetite among patients with stable heart failure. J Clin Nurs. 2016;25(11-12):1703-1712. doi:10.1111/jocn.13220

7. Pilgrim AL, Robinson SM, Sayer AA, Roberts HC. An overview of appetite decline in older people. Nurs Older People. 2015;27(5):2935. doi:10.7748/nop.27.5.29.e697

8. Wilson -M-MG, Thomas DR, Rubenstein LZ, et al. Appetite assessment: simple appetite questionnaire predicts weight loss in community-dwelling adults and nursing home residents. Am J Clin Nutr. 2005;82(5):1074-1081. doi:10.1093/ajcn/82.5.1074
9. Landi F, Russo A, Liperoti R, et al. Anorexia, physical function, and incident disability among the frail elderly population: results from the ilSIRENTE study. J Am Med Dir Assoc. 2010;11(4):268-274. doi:10.1016/j.jamda.2009.12.088

10. Andreae C, Strömberg A, Chung ML, Hjelm C, Årestedt K. Depressive symptoms moderate the association between appetite and health status in patients with heart failure. J Cardiovasc Nurs. 2018;33(2):E15-E20. doi:10.1097/JCN.0000000000000428

11. Schilp J, Wijnhoven HAH, Deeg DJH, Visser M. Early determinants for the development of undernutrition in an older general population: longitudinal aging study Amsterdam. Br J Nutr. 2011;106(5):708717. doi:10.1017/S0007114511000717

12. van der Pols-Vijlbrief R, Wijnhoven HAH, Schaap LA, Terwee CB, Visser M. Determinants of protein-energy malnutrition in community-dwelling older adults: a systematic review of observational studies. Ageing Res Rev. 2014;18:112-131. doi:10.1016/j.arr.2014. 09.001

13. Díez-Villanueva P, Alfonso F. Heart failure in the elderly. J Geriatr Cardiol JGC. 2016;13(2):115-117. doi:10.11909/j.issn.1671-5411.20 16.02.009

14. Uchmanowicz I, Kuśnierz M, Wleklik M, Jankowska-Polańska B, Jaroch J, Łoboz-Grudzien K. Frailty syndrome and rehospitalizations in elderly heart failure patients. Aging Clin Exp Res. 2018;30(6):617623. doi:10.1007/s40520-017-0824-6

15. World Medical Association. World medical association declaration of Helsinki: ethical principles for medical research involving human subjects. JAMA. 2013;310(20):2191-2194. doi:10.1001/jama.2013.281053

16. Vellas B, Guigoz Y, Garry PJ, et al. The Mini Nutritional Assessment (MNA) and its use in grading the nutritional state of elderly patients. Nutr Burbank Los Angel Cty Calif. 1999;15(2):116-122. doi:10.1016/ S0899-9007(98)00171-3

17. Hu L, Bentler PM. Cutoff criteria for fit indexes in covariance structure analysis: conventional criteria versus new alternatives. Struct Equ Model Multidiscip J. 1999;6(1):1-55. doi:10.1080/ 10705519909540118

18. Chan YH. Biostatistics 104: correlational analysis. Singapore Med J. 2003;44(12):614-619.

19. Nunnally JC. Psychometric Theory. 2nd ed. New York: McGrawHill; 1978.

20. R Core Team. $R$ : A Language and Environment for Statistical Computing. $R$ Foundation for Statistical Computing. Vienna, Austria; 2017. Available from: https://www.R-project.org/.

21. Winter JE, MacInnis RJ, Wattanapenpaiboon N, Nowson CA. BMI and all-cause mortality in older adults: a meta-analysis. Am J Clin Nutr. 2014;99(4):875-890. doi:10.3945/ajcn.113.068122

22. Danielsen R, Thorgeirsson G, Einarsson H, et al. Prevalence of heart failure in the elderly and future projections: the AGES-Reykjavík study. Scand Cardiovasc J SCJ. 2017;51(4):183-189. doi:10.1080/ 14017431.2017.1311023

23. Andreae C, Strömberg A, Sawatzky R, Årestedt K. Psychometric evaluation of two appetite questionnaires in patients with heart failure. J Card Fail. 2015;21(12):954-958. doi:10.1016/j.cardfail.20 15.10.006

24. Yaxley A, Crotty M, Miller M. Identifying malnutrition in an elderly ambulatory rehabilitation population: agreement between mini nutritional assessment and validated screening tools. Healthcare. 2015;3 (3):822-829. doi:10.3390/healthcare 3030822

25. Beaton D, Bombardier C, Guillemin F, Ferraz M. Recommendations for the Cross-Cultural Adaptation of the DASH \& QuickDASH Outcome Measures. 2nd ed. Toronto, Canada: Institute for Work \& Health; 2007.

26. Nessler J, Zalewski J, Kozierkiewicz A, et al. Project of comprehensive care program for patients with heart failure (KONS). Kardiologia Inwazyjna. 2018;13(6):10-17. 


\section{Publish your work in this journal}

Patient Preference and Adherence is an international, peer-reviewed, open access journal that focusing on the growing importance of patient preference and adherence throughout the therapeutic continuum. Patient satisfaction, acceptability, quality of life, compliance, persistence and their role in developing new therapeutic modalities and compounds to optimize clinical outcomes for existing disease

states are major areas of interest for the journal. This journal has been accepted for indexing on PubMed Central. The manuscript management system is completely online and includes a very quick and fair peer-review system, which is all easy to use. Visit http:// www.dovepress.com/testimonials.php to read real quotes from published authors.

Submit your manuscript here: https://www.dovepress.com/patient-preference-and-adherence-journal 